\title{
Challenges and Opportunities in Implementation of GST Bill for Insurance Sector in India
}

\author{
Sana Moid \\ Amity Business School, Amity University, Lucknow, India
}

Copyright $\mathrm{O} 2018$ by authors, all rights reserved. Authors agree that this article remains permanently open access under the terms of the Creative Commons Attribution License 4.0 International License

\begin{abstract}
The Indian economy is witnessing streamlined and focused efforts, of the kind off late for the implementation of the Goods and Service Tax (GST). With the services sector accounting for $60 \%$ of the GDP, the impact of GST on the service sector is likely to run deep. GST is undisputedly the single largest indirect tax reform since independence. It has the ability to change India's indirect taxation landscape and resulting in a positive impact on the entire economy. The present study is an attempt to understand the impact of GST on Insurance Industry along with highlighting the basic concept of GST, models of GST and its pros and cons in Indian context. The study also highlights the challenges in implementing the system. The introduction of GST will have a definitive impact on services offered by the life insurance sector. Seeking to levy GST on life insurance services would be in contrast to several countries where life insurance is a social security benefit being provided. Given the strategic importance of life insurance sector and the vast untapped market, it is believed that Government will address the concerns of the industry including ensuring merit rate of GST on insurance sector.
\end{abstract}

Keywords GST, Insurance Industry, Benefits, Challenges, Economy

\section{Introduction}

Introduction of VAT at the Central and the State level has been considered to be a major step in the direction of indirect tax reforms in India. If VAT is a major improvement over the pre-existing Central excise duty at the national level and the sales tax system at the State level, then the Goods and Services Tax (GST) is indeed an additional important perfection leading to widespread indirect tax reforms in the country. Initially, it was decided that there would be a national level goods and services tax but with the release of First Discussion Paper by the Empowered Committee of the State Finance Ministers it was made clear that there would be a "Dual GST" in India, both by them Centre and the State to levy the taxes on the Goods and Services. Almost 150 countries have introduced GST. Countries like Singapore and New Zealand tax everything at a single rate. Indonesia has five positive rates, a zero rate and over 30 categories of exemptions. In China, GST is applicable only to goods and provision of repairs, replacement and processing services. Under GST scheme, no distinction is made between goods and services for levying of tax. GST is a multi-tier tax where ultimate burden of tax fall on the consumer of goods/ services. It is called as value added tax because at every stage, tax is being paid on the value addition. Under the GST scheme, a person who was liable to pay tax on his output, whether for provision of service or sale of goods, is entitled to get input tax credit (ITC) on the tax paid on its inputs.

The introduction of GST is billed as a tectonic shift in the transaction tax regime prevalent in India, and is expected that the services sector would be impacted more in comparison to the manufacturing or trading sectors on certain parameters. Within the services sector, financial services (i.e. banking, broking) and insurance industries which have both $\mathrm{B} 2 \mathrm{C}$ and $\mathrm{B} 2 \mathrm{~B}$ operations will face incremental challenges due to the nature of their operations. Insurance Industry will be affected with the implementation of GST. Not only insurance industry, but also policy holders will be affected with GST implementation. Typically, policyholder's pay service tax on the risk element of the premium component whereas the investment element of the policies is usually out of the service tax scope.

\section{Literature Review}

Keeping the importance of GST in consideration, an announcement was made about the introduction of GST. The unique structure of India's Constitution comprising of Union Government at the Centre and the State Governments in the different Indian states has created a complicated and multi-layered system of consumption 
taxes.

Ahmad E. \& Poddar (2009) authors in the paper have discussed the proposed GST to be introduced in India, specifically in relation to the place of supply rules for services to be adopted, the method to apply dual GST i.e. how would the GST operate between states and the center, the tax rate to be applied etc. The authors have discussed the options to introduce the dual GST in India which could be Concurrent Dual GST, National GST or State GST. Under the concurrent dual GST the better option was the one where GST is applied on both goods and services. The other option explored was where the Central GST would be on goods and services but state GST would be only on goods since state to collect GST in services is difficult to determine.

Benedict, (2011) studied the provisions dealing with financial services under the Australian GST law with the intention to verify whether the provisions have been construed correctly in light of the original purpose of the legislation and how the concerns identified may be rectified. The author also examines the provisions followed in Australia to tax financial services provisions and whether the intention of the legislature in taxing the financial services is apposite. Through the paper the author has shown how clear-cut drafting of the said provisions has resulted in literal interpretation of the same by Courts and has therefore resulted in frustration of the legislative intention behind the provisions.

Borec, et al. (2013) authors are consultants with PwC Switzerland and have discussed how assesses may comply with the VAT laws given that the GST is a destination based tax. Effective 1 January, 2015, the place of supply rules have been modified to change the taxability of the services like telecommunication/broadcasting etc. in B2C cases from location of service provider to location of service recipient. The authors mainly deal with B2C cases where the VAT compliances would need to be done in the state where the customer is located.

Bovenberg, (1992) the author uses a general equilibrium model to assess different instruments of indirect taxation in middle income countries. The author has specifically studied Thailand and studied the impact of these different instruments on the revenue generation for government, their effectiveness.

Firth M. and Mckenzie K (2012) GST on financial services has always been a subject matter of great debate. There is a problem in taxing financial services due to their intangible nature, the confusion around the location of service provider and service recipient and the value of the service. The author in their paper is trying to address these issues especially for the country of Canada.

McMahon P. and Maclntyre A (2000) the authors have discussed the difficulties in taxing financial services under indirect taxation given the issues in valuing the said services. The problem is because of the fact that the margin or return on financial services is both for lending the money and for bringing the lender and borrower together. However, it is almost impossible to segregate the return for each individually.

Further they have discussed how the 'exempt' approach adopted to financial services leads to increase in the costs of financial services since the service providers are unable to take benefit of ITC involved in providing 'exempt' financial services. The paper also discusses other method like that followed by Australia of reduced ITC for e.g. it is currently $75 \%$ ITC allowed subject to certain conditions. The paper also discussed the Australian system which also has concepts like place of provision of services, facilitators of financial services which are taxed differently.

Parkhi, (2010) The author in the paper has discussed the concept of GST to be introduced in India, the background to GST and the method of collecting the proposed GST especially in light of the federal nature of administration in India. The author has discussed the various indirect taxes like VAT, excise etc. currently operating in India.

Agogo Mawuli (May 2014) studied in his "Goods and Service Tax-An Appraisal" and concluded that GST is not good for low-income countries and does not provide broad based growth for poor countries. Dr. R. Vasanthagopal (2011) concluded that switching to GST from current complicated indirect tax system in India will be a positive step in booming Indian economy. Success of GST leads to its acceptance by more than 140 countries in world and a new preferred form of indirect tax system in Asia also. Ehtisham Ahmed and Satya Poddar (2009) studied, "Goods and Service Tax Reforms and Intergovernmental Consideration in India" and found that GST introduction will provide a simple and transparent tax system with increase in output and productivity of economy in India. But benefits of GST are critically dependent on rational design of GST. Nitin Kumar (2014) concluded that implementation of GST in India will help in removing economic distortion by current indirect tax system and expected to encourage unbiased tax structure which is indifferent to geographical locations. Khurana et. al. (2016) in their study on GST- A positive reform for Indirect taxation system and concluded that the GST will provide relief to producers and consumers by providing wide and comprehensive coverage of input tax credit set-off, service tax set off and subsuming the several taxes. Sehrawat (2015) in her paper on GST in India - A key tax reform concluded that GST will give India a world class tax system by grabbing different treatment to manufacturing and service sector. Prajapati (2016) in his study on Challenges and Implementation of GST in India discussed about the challenges in implementation of GST like IT sector is not boomed, threshold limit of turnover for dealer sunder GST is another bone of contention between the government and the Empowered Committee etc. Shaik et.al, in their paper on Does Goods and Services Tax (GST) Leads to Indian Economic Development? Stated in conclusion that GST in the Indian framework will lead to 
commercial benefits that were unexplored by the VAT system and would essentially lead to economic development. Hence GST may usher in the possibility of benefit for industry, trade, agriculture and common consumers as well as for the Central Government and the State Government.

\section{Problem Statement}

Insurance services form the major crunch of the revenue generation of the country. Also the Government of India is mainly focused on the GDP growth of economy. Therefore, inclusion of insurance sector in GST Bill is quite significant. Globally several economies including Europe had insurance under the indirect taxes for more than a decade. With reference to the same, the present study attempts to study the benefits of including insurance sector in GST in the Indian context with a critical analysis of advantages and challenges in implementation.

\section{Objectives}

- To understand the concept of GST and its implementation in India.

- To highlight the advantages and understand the challenges of implementing GST in India.

- To explain the GST principles applicable to the insurance industry

- To highlight the importance of including insurance sector in GST in India.

- To offer policy recommendations and suggestions for implementation.

\section{GST}

Goods and Service Tax (GST) is a tax system levied on manufacturing, sales and consumption of goods and services at a national level. It a tax on goods and services with value addition at each stage having continuous chain of set-of benefits from the producer's/service provider's point up to the retailer's level where only the final consumer should bear the tax burden. The system of GST is based on the same concept as VAT. Instead of the set-off being available for the tax paid in the previous level in GST it would be charged only at the time of sale. Important points to be observed are:

- Components: GST will have two components: Central Goods and Service Tax and State Goods and Service Tax.

- Rate: Rates charged across all states and the central level will be uniform along with the regulations, definitions and classifications

- Applicability: GST will be applicable to all Goods and Services sold or provided in India, except for exempted goods which fall outside its purview.

Payment: GST will be charged and paid separately in case of Central and State level.

- Input Tax credit: The facility of Input Tax Credit at Central level will only be available in respect of Central Goods and Service tax. In other words, the ITC of Central Goods and Service tax shall not be allowed as a set-off against State Goods and Service tax and vice versa.

\section{Tax System under GST}

GST has merged the indirect central and state taxes into a four-tier schedule of 5, 12, 18 and 28 percent. While necessity goods is taxed at 5 percent and luxury and consumer durable goods at 28 percent, most goods and all services are taxed at the standard rates of either 12 or 18 percent.

\begin{tabular}{|c|c|c|c|c|}
\hline Items exempted & Items under $5 \%$ & Items under $12 \%$ & Items under $18 \%$ & Items under $28 \%$ \\
\hline $\begin{array}{l}\text { Milk, eggs, curd, buttermilk, } \\
\text { Fresh vegetables and fruits, } \\
\text { Un-branded wheat and rice, } \\
\text { un-branded flour, Puja Items }\end{array}$ & $\begin{array}{l}\text { Frozen Vegetables and fruits, } \\
\text { branded wheat and rice, branded } \\
\text { flour, hand-made safety matches, } \\
\text { cotton, cotton fabrics, Footwear } \\
\text { below Rs.500 }\end{array}$ & $\begin{array}{l}\text { Butter, Cheese, } \\
\text { Dry fruits, mobile } \\
\text { phones, ayurvedic } \\
\text { products }\end{array}$ & $\begin{array}{l}\text { Biddi wrapper leaves, } \\
\text { biscuits, footwear } \\
\text { exceeding Rs. } 500 \text {, } \\
\text { man-made fibre, hair } \\
\text { oil, soap, toothpaste }\end{array}$ & $\begin{array}{l}\text { Biris, LED TV, } \\
\text { AC, Cars, } \\
\text { tobacco } \\
\text { products, } \\
\text { cement }\end{array}$ \\
\hline
\end{tabular}




\section{Regulations of GST for Insurance Industry}

Post-liberalization, the insurance sector witnessed significant growth due to increased joining of private insurers, product innovation, and introduction of multiple distribution channels. This was further buoyant by the increase in the foreign direct investment (FDI) limit, from $26 \%$ to $49 \%$. Since then, insurance companies, along with the Insurance Regulatory and Development Authority of India (Irdai), have been making continuous efforts in developing the insurance sector in India. As a result, there is a significant increase in the number of private players operating in the market today, with a lot of product innovation catering to specific consumer needs.

In spite of all the progress in the sector, India is still a massively under-penetrated market. India is world's second most populous nation, and yet it accounts for less than $1.5 \%$ of the world's total insurance premiums and about $2 \%$ of the world's life insurance premiums.

Given the scenario, it is to be seen that how will the goods and services tax (GST) impact the growth momentum of this industry?

Of the four GST slabs-5\%, $12 \%, 18 \%$, $28 \%$-insurance is under the $18 \%$ slab, as against the previous service tax of $15 \%$. The increase in indirect taxation is opposite to the positive measures that have been taken over the last few years to develop this sector.

Governments across the world, even in the more mature markets, are known to create conditions favourable for insurance protection. In many countries, life insurance is outside the purview of GST.

In the Asia-Pacific, where some countries account for the world's highest insurance penetration, GST and value-added tax (VAT) are not levied on insurance products. Exceptions would be in China, where policies of less than one year attract a $6 \%$ tax and Taiwan and the Philippines, where tax of $2-5 \%$ is charged outside GST framework.

GST is a tax on value addition and net premium after deduction of claim is the net value addition. It is very difficult to demarcate the "savings" component and find a "value" that could be considered as the proper base for tax, particularly for every premium transaction during the life-cycle of an insurance policy.

Table 1. Impact of GST on Insurance Premium

\begin{tabular}{|l|c|c|}
\hline \multicolumn{1}{|c|}{ Type of Policy } & $\begin{array}{c}\text { After GST } \\
\text { Implementation }\end{array}$ & $\begin{array}{c}\text { Current } \\
\text { Rate }\end{array}$ \\
\hline Pure risk insurance/term insurance & $18 \%$ & $15 \%$ \\
ULIPs & $18 \%$ & $15 \%$ \\
Annuity: single premium & $1.8 \%$ & $1.5 \%$ \\
Motor insurance & $18 \%$ & $15 \%$ \\
Endowment Policies (1st year) & $4.5 \%$ & $3.75 \%$ \\
Endowment Policies (2nd Year & $2.25 \%$ & $1.88 \%$ \\
Onwards) & $18 \%$ & $15 \%$ \\
Health Insurance & & \\
\hline
\end{tabular}

Buying insurance will continue, provided insurance companies have the right kind of solution-based selling approach and to that extent, a favourable indirect taxation structure would have helped. Table 1 presents the change in the rate of insurance premium after implementation of GST.

For other life insurance products, as per GST rules, the value of services on which GST is to be imposed is calculated as the gross premium minus the amount allocated for investment. In case of single premium annuity policies, $10 \%$ of single premium is taxable. So, for an Rs 1 lakh premium, Rs 10,000 would be taxed at $18 \%$ now as against to $15 \%$ earlier. With the implementation of GST, a life insurance policy has now become dearer by 3 per cent. However, the amount of service tax will vary depending on the risk element embedded in the premium component and tax is levied only on the risk portion of the premium excluding the saving portion. As a result, the immediate impact of GST would be higher in term insurance and endowments plans. Life insurance provided by Government schemes are excused from GST. However, GST is not applicable on the following schemes.

- Janashree Bima Yojana (JBY)

- Varishtha Pension Bima Yojana

- Aam Aadmi Bima Yojana (AABY)

- Pradhan Mantri Jan Dhan Yojana

- Pradhan Mantri Vaya Vandana Yojana

- Pradhan Mantri Jeevan Jyoti Bima Yojana

- Life insurance provided by Central Government to members of the Army, Navy and Air Force.

- Life micro-insurance product with maximum cover of Rs. 50,000 approved by the Insurance Regulatory and Development Authority

- Any other State Government insurance scheme notified by Government of India on the recommendation of GSTC.

\section{Impact of GST on Businesses}

Sourcing: GST is likely to have a positive impact on Inter-state procurement. Manufacturers get the choice of consolidating supplies from vendors; Additional Duty/CVD and Special Additional Duty components of Customs Duty to be subsumed.

Distribution: The new regime has allowed consolidation and optimisation of warehouses; Current arrangements for distribution of finished goods to change; Current network structure and product flows may need review and possible alteration because of removal of Excise Duty.

Pricing and profitability: Tax changes resulting from the GST structure had led to repricing of Products resulting in bothway changes; Margins or price mark-ups would also need to be re-examined.

Cash flow: Removal of the concept of Excise Duty on manufacturing can result in improvement in cash flows and inventory costs as GST would now be paid at the time of sale/supply rather than at the time or removal of goods from the factory. 

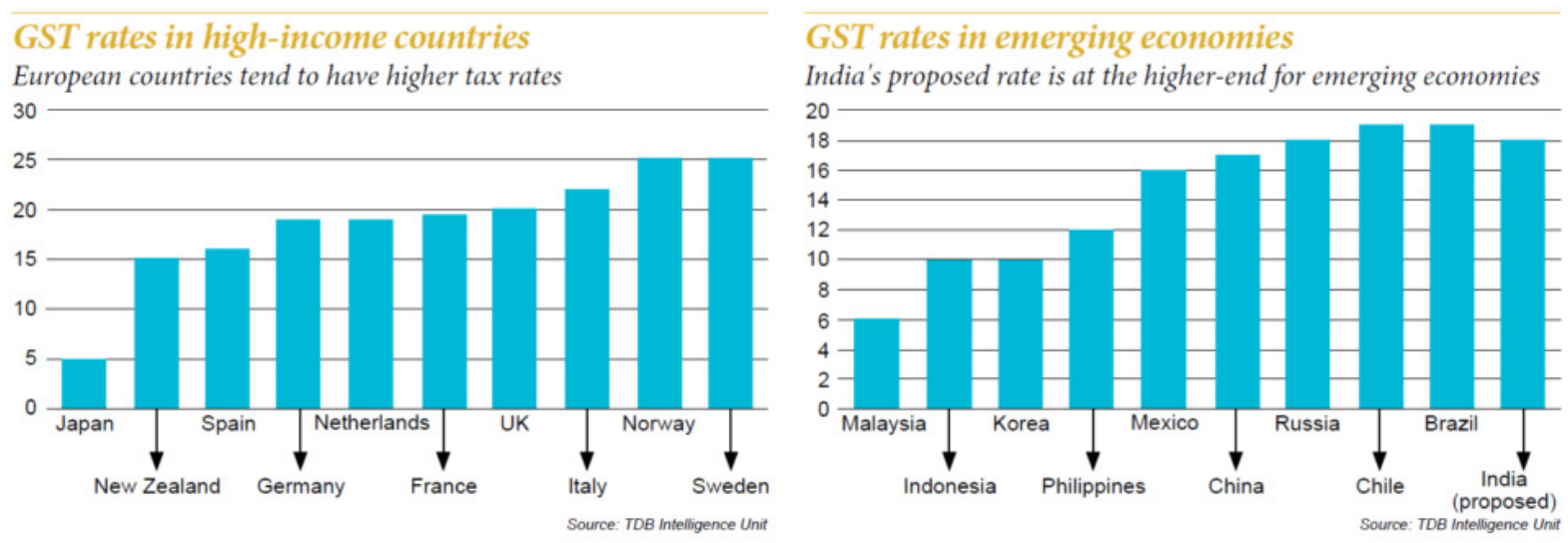

Graph 1. GST rates in high income countries and emerging economies

Changes in system and transaction management: Potential changes to accounting and IT systems in areas of master data, supply chain transactions, system design is required to be done; Existing open transactions and balances as on the cut-off date need to be migrated for ensuring smooth transition to GST; Changes to supply chain reports, other tax reports and forms (e.g., invoices, purchase orders) need review; Appropriate measures like training of employees, compliance under GST, customer education and tracking of inventory credit are needed to ensure smooth transition to the GST regime.

\section{Positive Effects of GST on Service Sector}

No double taxation: This was one thing that has affected many service providers. In the previous system of taxation, the works contract was complex. Here, the transfer of goods is a part of the service contract which means that every invoice has the value of goods used as well as the services supplied. These two attract a tax rate of $70 \%$ each bringing the total to $140 \%$ which is very high. With the implementation of GST, these two are considered to be one and thus taxed as 'supply of service.'

More Clarity for Software Industry: For companies that sell online software, it was not clear whether to apply VAT or Service Tax on the product. In GST regime, there is a clear demarcation between products and services which will remove the confusion for service industry.

Repairs and maintenance: The service providers that provide repair and maintenance services to companies will be able to claim both the credit of input and credit of input services as provided by the GST system. The current regime only offers the credit of input services which is a bit limiting. Now that they can claim both of the credit of input and credit of input services, they can offer their repair and maintenance services at lower prices and thereby attracting more clients.

Access to inputs held in stock: The service providers will access CENVAT credit of input that is held in stocks. This is best used when a person is moving from one category of taxation to the next like exemption category to the taxable one.

Fewer costs to service providers: In the previous system of taxation, the credit of VAT and CST that were paid to the input were billed to the service provider. With the GST system, the CENVAT credit of SGST/CGST, as well as the IGST that are to be paid on inputs and capital goods are all taken care of under the GST system. This is a relief to the service provider.

Equality in all states: The previous taxation system did not cover Jammu and Kashmir. Which presented a disadvantage to other places in India because taxation provisions. However, GST now covers the whole land bringing all service sectors under the same taxation laws.

\section{Negative Impacts of GST on Service Sector}

Lack of a centralized registration: With the previous taxation system, many service providers rejoiced over being able to register all their businesses in different areas from a central place. However, this privilege has been taken away. Now, they are required to register their businesses in the respective state and pay the CGST tax.

Taxation for free services: Business supplying services for free still had to get taxed for it. Every supply that is made without consideration is taxed.

Increased cost of service to end consumer: Because the rate of taxation is higher in the GST system, the end consumer will also feel a pinch of extra expenditure. The taxation is between $18 \%$ and $20 \%$. Because this rate is high, the cost of service will be higher.

Lack of a centralized system of accounting: Every business in every state need to have their accounting records because there is no centralized registration of businesses. Every business in every state is financially accountable to that state for taxation resulting in separate accounts of the business to be prepared.

The burden of public education: The business owner is charged with the responsibility of educating the masses on the benefits of this GST system. Failure of which may lead to unprecedented events. 


\section{Challenges and Opportunities of Implementing GST in Indian Context}

\section{Legislative Challenge}

The federal character of the constitution of India is essentially autonomy of the states to raise their own revenue and constitution provided the power to the union and state government to collect tax and levy tax as per the concurrent, union and states list. It restricts the government from bringing any change in this structure.

Benefit to the Indian Economy

The socio-economic conditions of the States in India are much different than the countries of the European Union. Hence, it is suggested that before implementing GST there should be a clear consensus whether there would be a net benefit for the Indian economy and/or whether Indian economy is ready to absorb the benefits of the GST regime.

\section{Consensus}

GST reflects the socio-economic conditions of countries differ; hence, a GST framework successful in any particular country may not necessarily be successful in other countries. Though GST has a number of administrative, compliance and other benefits, to what extent such a tax regime would be suitable in the socio-economic context of the Indian economy, is a matter of debate.

\section{Effective Credit Mechanism}

The success of GST model will depend on effective credit mechanism for avoiding cascading effect of multi-stage taxation in supply chain. The challenge for the government is to introduce a seamless mechanism of credit across India.

\section{Nature of Taxes}

The taxes that are generally included in GST are excise duty, countervailing duty, cess, service tax, and state level VATs among others. But, there are numerous other states and union taxes that would be still out of GST.

\section{Management and Infrastructure}

Success of any tax reform policy or managerial measures depends on the simplifications of the system, leading to high conformity with the administrative measures and policies. Simple system of the tax makes it more powerful.

\section{More Negotiation Is Required}

There are a number of issues on which negotiations are important for reaching a consensus between the centre and the states and among the states themselves. The first issue relates to the inclusion of taxes within the ambit of GST. The bone of contention relates to inclusion of purchase taxes on foodgrains, taxes on motor spirit and high speed diesel (GSD), and octroi or entry tax in lieu thereof.

\section{Opportunities}

\section{To Broaden the Tax Base}

The important gain from the GST reform are that it is expected to broaden the tax base, reduce distortions in the economy through a more comprehensive input tax credit, enhance export competitiveness by comprehensively relieving domestic consumption taxes on exports, ensure greater regional equity by getting rid of inter-state sales tax and having a destination-based tax, and help create a seamless national market by removing inter-state trade barriers.

\section{Reducing Cost for Taxpayers}

Reform is likely to reduce the compliance cost for taxpayers by simplifying and harmonizing the tax structure and by making the administration uniform across states.

\section{To End Cascading Effects}

It will be the major contribution of GST for the business. Currently, there are different state level and centre level indirect tax levies that are compulsory one after another on the supply chain till the time of its utilization.

\section{To Develop Harmonization}

Constitutional provision does not allow both the Central and State Governments to tax both goods and services in an inclusive manner. The government has therefore recognized the need for harmonization of goods and services tax so that both can be levied in a comprehensive and rational manner in a new taxation regime - namely, Goods and Services Tax (GST).

\section{Terminate Multiple Chain of Taxation}

The main benefit of Goods and Services tax is to eliminate multiple chain of the taxation. The terminate in the number of taxation applicable in a chain of transaction will help to clean up the current mess that is brought by existing indirect tax laws

\section{Relevance of GST}

Introduction of GST is likely to bring a sea change in the legal provisions for imposing duty/tax liability in stages of manufacture, sale (inter-state/intra-state) of goods, rendering services and shall stand replaced with the place of supply, where the final consumption and use of goods/services were made. Hence, this reform is necessary to be introduced to perceive the following benefits for the intended stakeholders:

\section{(A) To Trade}


- Reduction in multiple taxes

- Mitigation of double taxation

- Efficient neutralization of taxes especially for exports

- Development of Common National Market or Common Economic Market

- Simpler tax regime with fewer rates and exemptions

- Increase in cost competitiveness' for domestic industries with reduction in tax cost and also reduced cost of compliance

(B) To Government

- Simplifying tax system

- Broadening the tax base

- Improved compliance and revenue collections

- Efficient use of resources

- Investments out of savings by consumers - due to reduction of cascading effect, contributes to increase in availability of funds out of savings of consumer - which may be used for financing developmental activities

(C) To Consumer

- Reduction in cost of goods and services due to elimination of cascading effect of taxes

- Increase in purchasing power and real income

- Increase in savings due to decrease in cost

- Increase in investments due to increase in savings

\section{Advantages of GST}

Apart from full allowance of credit, there are several other benefits of introducing a GST in India:

Reduction in prices: Due to full and seamless credit, manufacturers or traders do not have to include taxes as a part of their cost of production, that is also a very big reason to say that we can see a reduction in prices. However, if the government seeks to introduce GST with a higher rate, this might be reduced.

Increase in Government Revenues: At the time of introduction of VAT, the public revenues actually went up instead of falling because many people resorted to paying taxes rather than evading the same.

Less compliance and procedural cost: Instead of maintaining big records, returns and reporting under different statutes, all assesses will find it convenient under GST as the compliance cost will be reduced. However, it should be noted that the assesses are, nevertheless, required to keep record of CGST, SGST and IGST separately.

\section{Challenges of GST in Indian Context}

Looking into the political environment of India, it seems that a little more time will be required to ensure that everybody is satisfied. There is confusion as to whether GST will hamper their revenues. Although it is assured by the Central Government to the states about compensation in case the revenue falls down. However, for the successful implementation of the same, there are few challenges which have to face to implement GST In India. Following are some of the factors that must be kept in mind about GST:

Firstly, it is mandatory that all the states implement the GST together and that too at the same rates. Otherwise, it will be really complicated for businesses to comply with the provisions of the law. Further, GST will be very beneficial if the rates are same, because in that case taxes will not be a factor in investment location decisions, and people will be able to focus properly on profitability.

For smooth functioning, it is important that GST clearly sets out the taxable event. Presently, the CENVAT credit rules, the Point of Taxation Rules are introduced for this purpose only. However, the rules should be more refined and free from ambiguity.

GST is a destination based tax and not on the basis of origin. In such cases, it should be clearly identified as to where the goods are going. This shall be difficult in case of services, because it is not easy to identify where a service is provided, thus it should be properly dealt with.

More awareness about GST and its benefits should be made.

\section{GST Models - Internationally}

Goods \& Services Tax (GST) is implemented by about 160 countries in the world. France being the first country to implement GST in 1960.There are various models of GST followed across the World with salient features associated therein:

Table 1. GST Models

\begin{tabular}{|l|l|l|}
\hline GST Model & Main Features & Applicable in Countries \\
\hline National GST & $\begin{array}{l}\text { Tax levied by Centre with provisions for revenue sharing with } \\
\text { Provinces/States }\end{array}$ & Australia, China \\
\hline State GST & Tax levied by Provinces/States & USA \\
\hline Non- concurrent Dual GST & GST on Goods levied by State \& on services levied by Centre & $\begin{array}{l}\text { Brazil \& Canada “ India's } \\
\text { Proposed Model” }\end{array}$ \\
\hline Concurrent Dual GST & Tax levied by Centre \& State on both Goods \& Services & \\
\hline Quebec Model & $\begin{array}{l}\text { Separate legislation for Federal/ Provinces- Tax collection, } \\
\text { Administration, Enforcements, etc. by Provinces }\end{array}$ \\
\hline
\end{tabular}


Statistical Analysis of Countries Implemented GST with rates of taxes:

Table 2. Tax Range Country Wise

\begin{tabular}{|c|c|c|c|}
\hline S. No. & Region & $\begin{array}{c}\text { No. of } \\
\text { Countries }\end{array}$ & $\begin{array}{c}\text { Tax Rate } \\
\text { (Range) }\end{array}$ \\
\hline 1 & $\begin{array}{c}\text { ASEAN- (Thailand\& } \\
\text { Philippines) }\end{array}$ & 7 & $7-12 \%$ \\
\hline 2 & Asia (Iran \& Tajikistan) & 19 & $5-20 \%$ \\
\hline 3 & $\begin{array}{c}\text { Europe (Jersey \& } \\
\text { Hungary) }\end{array}$ & 53 & $5-27 \%$ \\
\hline 4 & $\begin{array}{c}\text { Oceania (Niue \& New } \\
\text { Zealand) }\end{array}$ & 7 & $5-15 \%$ \\
\hline 5 & $\begin{array}{c}\text { Africa (Nigeria \& } \\
\text { Gambia) }\end{array}$ & 44 & $5-40 \%$ \\
\hline 6 & $\begin{array}{c}\text { South America (Brazil \& } \\
\text { Uruguay) }\end{array}$ & 11 & $10-22 \%$ \\
\hline 7 & $\begin{array}{c}\text { Caribbean, Central \& } \\
\text { North America (Canada } \\
\text { \& Barbados) }\end{array}$ & 19 & $5-17.5 \%$ \\
\hline \multicolumn{2}{|c|}{ Total No. of Countries } & 160 & \\
\hline
\end{tabular}

Source: GST in India Vol. 1 Report

\section{GST Models - Internationally}

Goods \& Services Tax (GST) is implemented by about 160 countries in the world, France being the first country to implement GST in 1960. There are various models of GST followed across the World with salient features associated there in:

Table 2. GST Models: Statistical Analysis of Countries Implemented GST with rates of taxes

\begin{tabular}{|c|c|c|}
\hline GST Model & Main Features & $\begin{array}{c}\text { Applicable in } \\
\text { Countries }\end{array}$ \\
\hline National GST & $\begin{array}{c}\text { Tax levied by Centre with } \\
\text { provisions for revenue sharing } \\
\text { with Provinces/States }\end{array}$ & Australia, China \\
\hline State GST & Tax levied by Provinces /States & USA \\
\hline $\begin{array}{c}\text { Non-concurrent } \\
\text { Dual GST }\end{array}$ & $\begin{array}{c}\text { GST on Goods levied by State } \\
\text { \& on services levied by Centre }\end{array}$ & \\
\hline $\begin{array}{c}\text { Concurrent Dual } \\
\text { GST }\end{array}$ & $\begin{array}{c}\text { Tax levied by Centre \& State } \\
\text { on both Goods \&Services }\end{array}$ & $\begin{array}{c}\text { Brazil \& Canada } \\
\text { "India's Proposed } \\
\text { Model" }\end{array}$ \\
\hline Quebec Model & $\begin{array}{c}\text { Separate legislation for Federal } \\
\text { /Provinces-Tax collection, } \\
\text { Administration, Enforcements, } \\
\text { etc. by Provinces }\end{array}$ & \\
\hline
\end{tabular}

Source: GST in India Vol.1 Report
Table 3. Tax Range Country Wise

\begin{tabular}{|c|c|c|c|}
\hline $\begin{array}{c}\text { S. } \\
\text { No. }\end{array}$ & Region & $\begin{array}{c}\text { No. of } \\
\text { Countries }\end{array}$ & $\begin{array}{c}\text { Tax Rate } \\
\text { (Range) }\end{array}$ \\
\hline 1 & ASEAN-(Thailand \& Philippines) & 7 & $7-12 \%$ \\
\hline 2 & Asia(Iran \& Tajikistan) & 19 & $5-20 \%$ \\
\hline 3 & Europe(Jersey \& Hungary) & 53 & $5-27 \%$ \\
\hline 4 & Oceania(Niue \& New Zealand) & 7 & $5-15 \%$ \\
\hline 5 & Africa(Nigeria \& Gambia) & 44 & $5-40 \%$ \\
\hline 6 & South America (Brazil \& Uruguay) & 11 & $10-22 \%$ \\
\hline 7 & $\begin{array}{c}\text { Caribbean, Central \& North } \\
\text { America (Canada \& Barbados) }\end{array}$ & 19 & $5-17.5 \%$ \\
\hline & Total No. of Countries & 160 & \\
\hline
\end{tabular}

Source: GST in India Vol.1Report

\section{GST Model for India}

India has opted for - Concurrent Dual GST model. The need for Dual-GST model is based on the following assumptions:

- At existing framework, both levels of Government i.e. Centre and State, as per Constitution holds concurrent powers for levying tax domestic goods and services;

- The proposed Concurrent Dual-GST model would be imposed concurrently by the Centre and the States, but independently;

- Both the Centre and State will operate over a common base for levy and imposition of duty/tax liability would be identical/ similar.

For understanding the operating procedure of Dual GST Model one has to consider the tax/taxes which shall be levied as per place of supply of goods and services.

- CGST - Central Goods and Service Tax

- $\quad$ SGST - State Goods and Service Tax

- $\quad$ IGST - Integrated Goods and Service Tax

Additional Tax (up to 1\%) is to be levied in case of inter-state supply of goods, which is a non-vatable item.

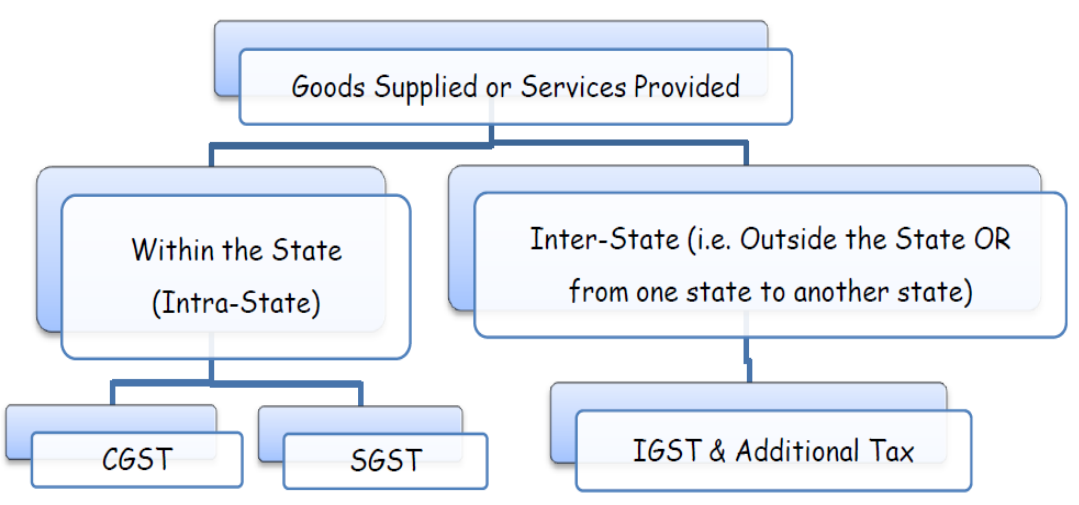

Source: GST in India Vol. 1 Report

Figure 1. GST Model in India 
Table 3. Summary of levy and the imposing and collecting authority

\begin{tabular}{|c|c|c|}
\hline Nature of levy & To be levied by & $\begin{array}{c}\text { To be paid } \\
\text { to the } \\
\text { account of }\end{array}$ \\
\hline CGST & $\begin{array}{c}\text { Central Government within } \\
\text { State Supply of Goods and/or } \\
\text { services }\end{array}$ & CG \\
\hline SGST & $\begin{array}{c}\text { State Government on within } \\
\text { State Supply of Goods and/or } \\
\text { services }\end{array}$ & SG \\
\hline IGST=CGST+SGST & $\begin{array}{c}\text { Central Government on Inter } \\
\text { State Supply of Goods and/or } \\
\text { services }\end{array}$ & CG \\
\hline Additional Tax & $\begin{array}{c}\text { Central Government on Inter } \\
\text { State Supply of Goods but } \\
\text { the net proceeds to be } \\
\text { assigned to the state from } \\
\text { where supply originates }\end{array}$ & CG \\
\hline
\end{tabular}

Source: GST in India Vol. 1 Report

\section{GST and Insurance}

With the new service tax rate, expected to be fixed at $18 \%$ under the GST regime, it is believed that higher tax rate will have a negative impact on the life insurance industry and the cost of insurance products on a larger picture. With the expected increase in the service tax rate from $15 \%$ to $18 \%$, the cost of buying the insurance policy and keeping the policy active will increase marginally.

Basically, premium of an insurance policy depends on the type of an insurance policy being purchased. Life insurance plans can be broadly categorized as term plans, endowment plans, ULIPs and pension plans.

Term Plan: The premium component of a term plan consists of majority of risk element for providing insured a risk cover throughout the tenure of the policy. At present, service tax of $15 \%$ is imposed on the premium cost of the plan. With GST, the tax is expected to rise to $18 \%$ in the first year and also on renewal premium from April 2017. This means the premium will get costlier by $3 \%$.

Endowment Plans: Currently, endowment plans attract a service tax of $3.75 \%$ on the premium in the first year of the policy and are expected to increase to $4.5 \%$ in the first year under GST. As of now, $1.88 \%$ of the service tax is levied on endowment plan's premium for the second year which is expected to rise to $2.25 \%$ from the second year onwards after the implementation of GST.

\section{ULIP}

Unit Linked Insurance Plans (ULIPs) also offer dual advantage of insurance and investment. At present, service tax of $3.5 \%$ is levied on protection part of ULIPs in the first year and $1.75 \%$ from second year onwards. This would go up to $4.5 \%$ in the first year and $2.25 \%$ from second year onwards after implementation of GST.

\section{Health Insurance Plan}

Currently, health plan premium attracts a service tax of
$15 \%$ on its premium cost. With the implementation of GST, the cost of acquiring the health insurance will become expensive as it will attract tax of about $18 \%$ on premium.

\section{Motor Insurance}

Motor insurance premium also attracts the service tax of $15 \%$ which will rise to $18 \%$, if the rate is fixed up to this specified percentage mark.

\section{What this Means for the Insurance Industry}

So with insurance premiums all set to increase, there is going to be a war between different insurance companies in the market, as people will now be more averse to invest. And it does not spell good news because the insurance industry has been gradually moving down despite all the predictions of boom. The Life Insurance Council has already written to the finance ministry, urging that GST be charged only on premium collected by the insurer, for their life insurance services, without involving in the investment portion, where the companies act solely in the fiduciary capacity.

The goods and services tax (GST) will significantly affect the insurance industry due to the emergence of dual stakeholders in every taxable supply of service: the government of the state where the supply is made and the central government.

\section{Gearing Up for GST: Snapshot}

- As Insurance is a service industry, it deals with single tax (Service tax) with one administering authority (Central Government)

- Under the dual GST structure, one from the Central, one from the state, insurers will potentially start dealing with 38 taxes, 35 State and Union Territories GSTs and One Central GST and IGST on interstate supplies.

- Currently the location of policy holder does not affect insurer but under GST they will have to take note of resident locations.

- Location of the acquiring distribution channel will have to be evaluated as under the current structure, customers can be acquired across the country.

- To assess the location of office from which insurance is being sold for tax purpose, the operating framework will have to be seen in a centralized versus decentralized manner as the taxes could accordingly vary.

Insurers need to ensure that their GST implementation plan achieves the main objective of zero business disruption and $100 \%$ compliance. One of the important success factors for a business to smoothly transform into the GST regime would be the process-readiness and technology-readiness to take on not only higher 
compliances, but also transaction-level reporting : a new concept in the prevalent indirect tax regimes.

The GST regime is likely to throw up interesting opportunities and challenges for insurers. They need to consider GST as a business transformation lever to strengthen their present business processes, identify opportunities and have a first-mover advantage.

\section{Impact on Insurance Premiums}

Now when the GST finally goes live, all these taxes will be merged into one. How insurance premiums will be affected depends on the final GST taxation value that will be decided. The insurance industry will see an increase in the insurance premiums that insurers have to pay, albeit the surge may not be as much as some of the other industries might face. It will be approximately 3 percent or in technical terms, 300 basis points.

In case GST service tax is set around 18 percent, the concessional tax rates on these endowment and ULIP policies will be revised too. So, under new GST regime, the concessional tax rate on the first premium will be 4.5 percent and the same on the renewal premiums will be lugged up to 2.25 percent. It is evident that in long term, these would not account to small amounts.

\section{Impact of GST on Non-life Insurance Premiums}

Non-life insurance premiums can be health policies, home insurance, or motor insurance. For these policies, you pay the premium that will be used to compensate the loss as and when you encounter it.

Under the current regime, all non-life insurance policies are charged at 15 percent of the service tax. So this will also go up by 3 percent, meaning the new rate will be as high as 18 percent.

Table 4. Revision in Premium Rate after GST

\begin{tabular}{|c|c|c|}
\hline Nature of insurance policy & $\begin{array}{c}\text { Rate before } \\
\text { GST }\end{array}$ & $\begin{array}{c}\text { Rates after } \\
\text { GST }\end{array}$ \\
\hline Pure risk insurance/term insurance & $15 \%$ & $18 \%$ \\
\hline ULIPs & $15 \%$ & $18 \%$ \\
\hline Annuity: single premium & $1.5 \%$ & $1.8 \%$ \\
\hline Motor insurance & $15 \%$ & $18 \%$ \\
\hline Endowment policies (1st year) & $3.75 \%$ & $4.5 \%$ \\
\hline $\begin{array}{c}\text { Endowment policies (2nd year } \\
\text { onwards) }\end{array}$ & $1.88 \%$ & $2.25 \%$ \\
\hline Health insurance & $15 \%$ & $18 \%$ \\
\hline
\end{tabular}

The gross premium minus the amount allocated for investment, or savings on behalf of the policyholder, if such amount is informed to the policyholder.

For example,

\begin{tabular}{|c|c|c|}
\hline Particulars & Under Service Tax & Under GST \\
\hline Gross Premium & 1000 & 1000 \\
\hline Investment Portion & 600 & 600 \\
\hline Life Insurance portion & 400 & 400 \\
\hline Service tax @ 15\% on 400 & 60 & - \\
\hline GST @18\% on 400 & - & 72 \\
\hline
\end{tabular}

b) Single premium annuity policies- $10 \%$ of the premium

c) All other cases- $25 \%$ for 1 st year and $12.5 \%$ for 2 nd year onwards on the premium charged.

\begin{tabular}{|c|c|}
\hline Gross Premium p.a. & 1000 \\
\hline 1st Year & \\
\hline $25 \%$ of value & 250 \\
\hline GST @18\% on 250 & 62.5 \\
\hline 2 d d year & \\
\hline $12.5 \%$ of value & 125 \\
\hline GST @18\% on 125 & 22.5 \\
\hline
\end{tabular}

If the entire premium is for life insurance, GST @18\% will apply on the entire premium.

\section{Findings and Suggestions}

GST implementation has to be done keeping in mind the inherent nature of insurance business. Currently, the location of a policyholder, be it a corporate or an individual, does not affect insurers, considering that any insurance transaction in the country is subject to central service tax (unless specifically exempted). Given the changed tax regime with GST, insurers would need to increasingly focus on the following points as part of their customer-acquisition strategy:

Customers' resident location: As SGST gets implemented insurers will need to improve their processes, architecture and controls to capture this information to ensure compliance.

Location of the acquiring distribution channel: Given the various operating models across distribution channels, it will be of importance to critically evaluate the current distribution structure, where customers could be acquired across the country with distributors being located centrally or regionally in a separate state.

Policy issuance and servicing framework: To assess the location or office from which insurance is being sold for tax purposes, it will be important to evaluate the operating framework in a centralized versus decentralized manner as the taxes could accordingly differ. The draft law, for example, does not clearly specify how to determine which office of the insurer is providing the insurance service; it is vaguely defined as the registered office providing the service.

This is likely to lead to discussion on whether it is the office centrally signing and issuing the policy or the office where the policy is being logged in or service being provided. So, determination of the office of the insurer as well as the office of the insured will be critical for tax compliances going forward.

The Union Budget of 2017-18 has made the following provisions for the Insurance Sector:

- The Budget has made provisions for paying subsidies in the premiums of Pradhan Mantri Fasal 
Bima Yojana (PMFBY) and the number of beneficiaries is likely to increase to 50 per cent in the next two years from the present level of 20 per cent. As part of PMFBY, Rs 9,000 crore (US\$ 1.35 billion) has been allocated for crop insurance in 2017-18.

- $\quad$ By providing tax relief to citizens earning up to Rs 5 lakh (US\$ 7500), the government will be able to increase the number of taxpayers. Life insurers will be able to sell them insurance products, further reducing the tax burden in future. As many of these people were understating their incomes, they were not able to get adequate insurance cover.

- Demand for insurance products may rise as people's preference shifts from formal investment products post demonetization.

- The Budget has attempted to hasten the implementation of the Digital India initiative. As people in rural areas become more tech savvy, they will use digital channels of insurers to buy policies.

The delivery process may also get affected because of the state tax implications: centralized credit versus regional disbursement versus branch options. Insurers need to build internal controls to track the payment of tax by distributors, for ensuring compliance. Decision making for procurements and vendor management will be governed by GST guidelines. Many insurers may look at decentralizing procurements. Re-look need to be done at insurer's end, where state tax liabilities need to be mapped along with required state input tax credits for avoiding any blockages of credits.

A similar re-look will need to be done at the insurer's end, where state tax liabilities need to be mapped along with the relevant state input tax credits in order to avoid any blockages of credits.

Motor vehicle insurance would be a classic case, where credits of the network third parties will accrue in the state where repair services are availed by the policyholder but the tax liability for the insurance company on that policy may not be in the same state. Sufficient preparations need to be made by both Central and State governments for implementing GST at all levels.

- Besides Government, there could be other professional bodies that could assist in the execution of the proposed system

- Tax-payers should be clear about the system and the mechanism of GST.

- Alternative schemes should be offered to those who could be adversely affected.

- Policies should be framed to protect the interest of the SSI and small traders who could be adversely affected.

\section{GST: Journey so Far - Fusion, Fission and Confusion}

Multiple taxation during supply chain without right to claim input tax credit made most goods and services costly.
This is a single most important reason why businessmen are eager to welcome GST. The Government has proclaimed that GST is integration of all indirect taxes into one tax - it is fusion of taxes. One nation One tax is how the Government is promoting this change. Section below presents the real situation versus the claims projected by the system:

\section{Claim: There will be few tax rates applicable}

Reality: There are 7 different tax rates $0 \%, .25 \%, 3 \%$, $5 \%, 12 \%, 18 \%, 28 \%$. If one considers the compensation cess number will shoot up further. Rates of taxes for services are separate with conditions about input tax credit will end up in factual different rates for such services. With pressure from varied sectors number of tax rates may go up further.

\section{Claim: Full seamless Input tax credits will be allowed}

Reality: There are varied terms and conditions for availing tax credits. The list of blocked credit is very long. No input tax credit for exempt supplies mean that the value of exempt supplies is inclusive of taxes. Various formulas are there targeted to reduce the input tax credits. For a common man it is difficult to understand those formulas. In addition rate schedule for multiple services have a provision that it is without input tax credit or with restricted input tax credits. Tax on advance received is another impediment to seamless credit. Refund of accumulated credit will not be allowed. Cenvat credit which was available on pan India basis is now fragmented into 30 states and union territories

\section{Claim: System will be simple}

Reality: In addition to complexity of understanding what is goods and service and different tax rates and input credit provisions the entire system is made further complicated. It has taken concepts from existing laws and put them together. It has borrowed reverse Charge from service tax. Tax collection at source is taken from VAT. Tax deduction at source is from works contract. Job work concept is from central excise. Related party transaction is a concept from customs. Most of these have no significant relevance with VAT system of taxation. It has made the system most complex. Reverse charge tax on inputs from unregistered person has worsened the situation. It will increase the unnecessary clerical work without any substantial revenue gain for Government.

\section{Conclusions}

Tax policies play an important role on the economy because of their impact on efficiency and equity. A good tax system should keep in view issues of income distribution and, at the same time, also endeavor to generate tax revenues for supporting government 
expenditure on public services and infrastructure development. The ongoing tax reforms on moving to goods and services tax would affect the national economy, International trade, firms and the consumers There has been a good deal of criticism as well as appraisal of the proposed Goods and Services Tax regime. It is considered to be a major improvement over the pre-existing central excise duty at the national level and the sales tax system at the state level, the new tax will be further significant breakthrough and the next logical step towards a comprehensive indirect tax reform in the country. GST is not simply VAT plus service tax, but a major improvement over the previous system of VAT and disjointed services tax - a justified step forward

Due to unstable environment of Indian economy, it is demand of time to implement GST. Consumption and productions of goods and services is undoubtedly increasing and because of multiplicity of taxes in current tax regime administration complexities and compliance cost is also accelerating. Thus, a simplify user -friendly and transparent tax system is required which can be fulfilled by implementation of GST.

GST is the most logical steps towards the comprehensive indirect tax reform in our country since independence. GST is leviable on all supply of goods and provision of services as well combination thereof. All sectors of economy whether the industry, business including Govt. departments and service sector shall have to bear impact of GST. All sections of economy viz., big, medium, small scale units, intermediaries, importers, exporters, traders, professionals and consumers shall be directly affected by GST.

The insurance industry is also not going to remain unaffected from its impact. It will certainly going to have an impact on the insurance industry as well as policyholders. Typically, policyholder's pay service tax on the risk element of the premium component whereas the investment element of the policies is usually out of the service tax scope. With the implementation of the GST, insurance policies including life, health and motor will all be costlier

Insurers need to ensure that their GST implementation plan achieves the key objectives of zero business disruption and $100 \%$ compliance. One of the critical success factors for a business to smoothly transition into the GST regime would be process-readiness and technology-readiness to take on not only higher compliances, but also transaction-level reporting - a novel concept in the prevalent indirect tax regimes. Gearing up to ensure that all transactions are appropriately mapped and measured would be essential. The GST regime is likely to throw up interesting opportunities and challenges for insurers. They need to consider GST as a business transformation lever to strengthen their present business processes, identify opportunities and have a first mover advantage.

\section{REFERENCES}

[1] Ahmad E. and Poddar S., (2009), GST Reforms and Intergovernmental Considerations in India, Asia Research Centre, Working Paper 26, Pg. 1-43

[2] Benedict K., (2011), The Australian GST regime and financial services: How did we get here and where are we going?, E Journal of Tax Research, Vol. 9, (Issue 2), Pg. 174-193

[3] Borec T. and Merz M. and Salanki A., (2013), World Wide VAT Forum: E Commerce, Tax Planning International Indirect Taxes, Vol. 5, Pg. 13-15

[4] Bovenberg A.,(1992), Indirect taxation in developing countries, International Monetary Fund - Staff Papers, Vol. 1, Pg. 333-373

[5] McMahon P. and Maclntyre A., (2000), GST and Financial Supplies, Journal of Australian Taxation, Issue 3, Pg. 167-197

[6] Parkhi S., (2010), Goods and Service Tax: The changing face of the Economy, Pg. 1-15

[7] ICAI (2015),An Insight of GST in India, Tax Research Department

[8] Poddar S, Ahmad E (2009), GST Reforms and Intergovernmental Considerations in India, Working Paper No.1/2009-DEA, Department of Economic Affairs Ministry of Finance, Government of India.

[9] Prajapti, H (2016) "Challenges and Implementation of GST (Goods and Service Tax) in India" Paripex - Indian Journal Of Research, 2(12), pp20-35.

[10] Kamna S, Verma R (2014), "Good and Service Tax Panacea For Indirect Tax System In India", "Tactful Management Research Journal”, 12(10)

[11] Mawuli, A (2014): "Goods and Service Tax-An Appraisal" Paper presented at the PNG Taxation Research and Review Symposium, Holiday Inn, Port Moresby, pp. 29-30.

[12] Shaik, S, Sameera, S, AFiroz, K, C. (2015) "Does Goods and Services Tax (GST) Leads to Indian Economic Development?" IOSR journal of business and management. 17(12), pp. 1-05.

[13] Sehrawat, M, Dhanda U, "GST in India - Akey tax reform” International journal of researchGranthalya.3(12), pp. No.133-141

[14] Vasanthagopal, .R (2011), "GST in India: A Big Leap in the Indirect Taxation System”, International Journal of Trade, Economics and Finance, 2(2).

[15] https://gst.registrationwala.com/gst-impact/impact-of-gst-o n-the-insurance-industry accessed on 4/06/2017

[16] http://www.moneycontrol.com/news/business/economy/gstrate-shocker-for-insurance-sector-premiums-may-go-up-3-2 284323.html accessed on 4/06/2017

[17] http://timesofindia.indiatimes.com/business/india-business/i nsurance-premiums-set-to-go-up-under-gst-regime/articlesh ow/58769785.cms accessed on 5/06/2017

[18] http://www.livemint.com/Money/6ldwh1RVp5e8VEgdyY 
O32J/Both-state-and-Centre-to-be-stakeholders-in-insuranc e-sector.html accessed on 5/06/2017

[19] https://www.policyx.com/blogs/gst-and-its-impact-on-insur ance/ accessed on 6/06/2017

[20] https://www.policymantra.com/articles/impact-of-gst-on-in dian-insurance-sector accessed on 6/06/2017
[21] http://www.indiainfoline.com/article/general-blog/impact-o f-gst-on-the-life-insurance-sector-116120200322_1.html accessed on $6 / 06 / 2017$

[22] http://taxguru.in/goods-and-service-tax/gst-journey-fusion-f ission-confusion.html accessed on 7/06/2017 